\title{
TEKNIK PENILAIAN BERBASIS KELAS DAN KONSEP DIRI DALAM PEMBELAJARAN BIOLOGI
}

\section{Siti Nurasiah}

Universitas Negeri Jakarta, DKI Jakarta

\section{Gaguk Margono}

FT Universitas Negeri Jakarta, Jakarta Timur

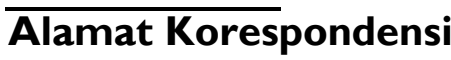 \\ e-mail: \\ sitinurasiah33@gmail.com
}

\begin{abstract}
This study was conducted in SMAN I Cilamaya Karawang. The samples were 80 students of $I^{\text {th }}$ grade of Science Major in the second semester of the 2015/2016 academic year. Samples were selected by using simple random sampling technique. The research method adopted was the experimental method. While the study design is the treatment by level $2 \times 2$ design. The data collection was done by measuring the academic self concept of students and students'biology learning outcomes. The hypothesis was tested by using analysis of variance (ANOVA). The research result has a positive impact on improving the evaluation system of learning in high school as well as improvement in student's biology learning outcomes.
\end{abstract}

Keywords
CATs, minute paper, muddiest point, academic self concept

\begin{abstract}
ABSTRAK
Penelitian ini dilakukan di SMAN I Cilamaya Kabupaten Karawang. Sampel penelitian ini adalah 80 siswa kelas XI program IPA pada semester genap tahun ajaran 2015/2016. Sampel penelitian dipilih dengan menggunakan teknik sampel acak sederhana. Metode penelitian menggunakan metode eksperimen sedangkan desain penelitian menggunakan desain treatment by level $2 \times 2$. Pengumpulan data dilakukan dengan mengukur sikap pengambilan resiko siswa dan hasil belajar biologi siswa. Hipotesis penelitian diuji dengan menggunakan analisis varian (ANAVA) dua jalan. Hasil penelitian berimplikasi positif pada upaya peningkatan sistem evaluasi pembelajaran di Sekolah Menengah Atas serta peningkatan hasil belajar biologi siswa.
\end{abstract}

Kata Kunci

CATs, minute paper, muddiest point, konsep diri akademik

\section{Pendahuluan}

Penilaian berbasis kelas merupakan suatu pendekatan yang dirancang untuk menolong pendidik dalam memahami, apakah peserta didik belajar selama proses pembelajaran berlangsung, dan bagaimana sebaiknya mereka mempelajarinya. Penilaian berbasis kelas adalah cara sederhana yang dapat digunakan pendidik untuk mengumpulkan balikan (feedback) lebih awal dan seringkali; tentang bagaimana sebaiknya peserta didik belajar mengenai hal-hal yang telah dibelajarkan (Yusuf, 20I5).

Rendahnya hasil belajar biologi tentunya dipengaruhi beberapa faktor, salah satu kemungkinan adalah kurang komprehensifnya tipe penilaian yang dilaksanakan. Perolehan rata-rata nilai Biologi pada UN 2015 Kabupaten Karawang adalah 42,6I sedangkan rata-rata nilai UN Biologi Provinsi 63,85 dan rata-rata nilai UN Biologi Nasional adalah 64,04. Dapat diartikan bahwa nilai rata-rata UN Biologi Kabupaten Karawang jauh di bawah rata-rata nilai provinsi dan nasional. Demikian pula di SMA Negeri I Cilamaya hasil belajar Biologi dapat dilihat dari perolehan ratarata nilai UN Blologi adalah 29,8I di bawah ratarata nilai kabupaten.

Melakukan teknik penilaian berbasis kelas (Classroom Assessment Techniques = CATs) dapat menjadi solusi dalam menilai tingkat pencapaian hasil belajar siswa. Dua teknik yang digunakan dalam penelitian ini adalah: minute paper dan muddiest point. Kedua teknik ini adalah teknik penilaian berbasis kelas (CATs) yang diberikan kepada siswa setiap akhir pertemuan.

Kenyataan di kelas menunjukkan penilaian yang biasa dilakukan hanya berupa tes tertulis pada akhir KD baik berupa pilihan ganda maupun essay. Penggunaan penilaian berbasis kelas yang menyatu dalam proses pembelajaran, akan memberikan dampak positif pada guru yang membelajarkan 
dan siswa dalam belajar. Apabila asesmen kelas dilaksanakan secara kontinu dan tepat guna dalam setiap kegiatan pembelajaran, maka asesmen kelas mampu memperbaiki kualitas pembelajaran dan kualitas belajar peserta didik (Yusuf, 20I5).

Terdapat berbagai tipe penilaian berbasis kelas diantaranya adalah: minute paper dan muddies point. Minute paper adalah salah satu teknik dari CATs yang sering digunakan mengandung dua pertanyaan mengenai apa saja yang sudah dimengerti siswa dari materi yang sudah dipelajari. Sedangkan muddiest point lebih menitikberatkan kepada menanyakan bagian yang belum dipahami dari pembelajaran tersebut. Muddiest point adalah salah satu CATs paling sederhana untuk membantu menilai siswa mana yang mengalami kesulitan.

Dari dua CATs tersebut menggambarkan bahwa suatu teknik yang dilakukan pada setiap akhir pembelajaran yang menggali ketercapaian belajar siswa dan ketidaktercapaian hasil belajar siswa yang biasanya hanya diukur dengan soal tes akhir atau tes formatif saja.

Pemilihan CATs, yaitu: minute paper adalah lebih karena dari perkiraan waktu dan energi yang digunakan adalah rendah baik yang dibutuhkan untuk sekolah menyiapkan penggunaannya, respon siswa dalam penilaian, dan sekolah menganalisis data hasil yang sudah dikumpulkan (Anggelo dan Cross, 1993).

Pada muddiest point siswa harus dengan cepat mengidentifikasi apa yang mereka tidak mengerti atau masih belum jelas. Sementara waktu yang digunakan untuk penilaian ini sangat singkat. Kemungkinan siswa kesulitan dalam menuliskan hal-hal yang belum dipahami atau hal yang paling tidak dimengerti oleh siswa.

Selain pemberian CATs, faktor internal yang diduga kuat mempengaruhi keberhasilan belajar biologi adalah konsep diri siswa. Konsep diri merupakan cara pandang seseorang terhadap dirinya, dalam hal ini cara pandang siswa terhadap dirinya sehubungan dengan hasil belajar Biologi. Bila memiliki konsep diri yang tinggi individu akan mengembangkan sifat-sifat seperti rasa percaya diri, harga diri, dan kemampuan untuk melihat dirinya sendiri secara realistis (Hurlock, 1996). Bila memiliki konsep diri yang rendah, individu akan mengembangkan perasaan tidak mampu, rendah diri, dan kurang percaya diri, yang akan menumbuhkan penyesuaian diri dalam interaksi diri secara pribadi dan lingkungan yang buruk.

Berdasarkan uraian tentang konsep diri tinggi dan konsep diri rendah beserta dengan ciricirinya, dapat dikatakan bahwa konsep diri mempunyai peranan yang cukup penting dalam meningkatkan hasil belajar siswa.

Mengacu pada beberapa pernyataan yang telah dikemukakan terdahulu, maka konsep diri dalam penelitian ini lebih diarahkan pada konsep diri akademis, yaitu: konsep diri yang berkaitan dengan aktivitas-aktivitas belajar seorang siswa pada mata pelajaran biologi.

Penggunaan teknik penilaian berbasis kelas (CATs) dalam hal ini penggunaan muddiest point dan minute paper adalah mengkondisikan siswa agar dapat mengungkapkan hal-hal yang sudah dimengerti dan belum dipahami dari apa yang dipelajari dalam setiap tatap muka. Hal tersebut melatih siswa untuk percaya diri mengungkapkan kesulitan dalam belajar dan kemampuan dalam belajar. Dalam penelitian ini diharapkan konsep diri mampu mempengaruhi siswa untuk meningkatkan hasil belajar pada pelajaran Biologi.

Diduga terdapat pengaruh teknik penilaian berbasis kelas dan konsep diri terhadap hasil belajar siswa. Oleh karena itu penelitian ini bertujuan untuk mengkaji pengaruh pemberian teknik penilaian berbasis kelas dan konsep diri terhadap hasil belajar biologi perlu dilakukan.

\section{Metode Penelitian}

Penelitian ini menggunakan metode eksperimen dengan desain treatment by level $(2 \times 2)$. Variabel perlakuan dalam penelitian ini adalah teknik penilaian berbasis kelas (CATs), sedangkan variabel atribut adalah konsep diri akademik pada mata pelajaran biologi. Variabel terikat pada penelitian ini adalah hasil belajar biologi siswa.

Populasi target dalam penelitian ini adalah seluruh siswa SMA Negeri I Cilamaya Kabupaten Karawang. Sedangkan populasi terjangkau pada penelitian ini adalah siswa kelas XI SMAN I Cilamaya. Populasi kelas XI tersebut terdiri dari lima kelas dengan total 203 siswa. Semua siswa kelas XI tersebut memiliki peluang yang sama untuk terpilih sebagai sampel dalam perlakuan ini. 
Teknik pengambilan sampel dalam penelitian ini menggunakan teknik simple random sampling (Sanjaya, 20l3), yaitu: cara pengambilan sampel secara sederhana dari anggota populasi dilakukan secara acak tanpa memperhatikan strata (tingkatan) dalam anggota populasi tersebut.

Eksperimen dilakukan dengan cara memberi perlakuan berupa teknik penilaian minute paper dan teknik penilaian muddiest point dilakukan secara sistematis sebanyak 4 kali dalam masa 4 kali pertemuan pembelajaran. Di mana dilakukan setiap akhir pelajaran dan perbaikan dilakukan sebelum pelajaran dilanjutkan pada pertemuan berikutnya. Setelah pembelajaran selama 4 kali pertemuan dilanjutkan dengan melakukan tes hasil belajar. Untuk menghindari bias dalam penelitian maka perlu dilakukan pengontrolan terhadap validitas internal dan validitas eksternal eksperimen.

Dalam penelitian ini terdapat dua macam data yang dikumpulkan melalui instrumen penelitian, yaitu: data hasil belajar biologi siswa dan data konsep diri akademik siswa. Instrumen tes hasil belajar biologi siswa digunakan untuk mengukur hasil belajar siswa setelah mendapatkan perlakuan. Instrumen tes hasil belajar biologi dikembangkan oleh peneliti, terdiri dari 32 butir soal pilihan ganda materi pelajaran biologi SMA kelas XI semester II tahun pelajaran 2015/2016 mengenai pokok bahasan sistem ekskresi, dengan koefisien reliabilitas konsistensi internal sebesar 0,953. Instrumen konsep diri akademik, peneliti mengadaptasi dari skala Self Descrition Questionnaires II (SDQ II) oleh Marsh (I992) yang item-item dalam setiap domainnya dimodifikasi agar dapat mengukur konsep diri akademik pada situasi pembelajaran di sekolah khususnya pembelajaran biologi, terdiri dari 22 butir dengan koefisien reliabilitas konsistensi internal sebesar 0,914 .

Normalitas data diuji dengan menggunakan uji Lilliefors, sedangkan homogenitas varians diuji dengan menggunakan uji Bartlett. Hipotesis penelitian diuji dengan menggunakan teknik analisis varians (ANAVA) dua jalur dilanjutkan dengan uji pengaruh sederhana (simple effect) menggunakan uji t-Dunnet.

\section{Hasil Penelitian dan Pembahasan}

Hasil pengujian hipotesis penelitian menggunakan teknik analisis varians (ANAVA) dapat dilihat pada Tabel I.

Tabel I. Hasil Analisis Varians Data Penelitian

\begin{tabular}{lccccc}
\hline \multicolumn{1}{c}{ Sumber Varians } & db & JK & RJK = s2 & F-hit & F-tabel \\
\hline Antar Kolom (A) & $\mathrm{I}$ & 2508.800 & 2508.8 & 285.2188 & $\mathbf{0 . 9 5}$ \\
\hline Antar Baris (B) & $\mathrm{I}$ & 174.050 & 174.050 & 19.78728 & 3.97 \\
\hline Interaksi (AB) & $\mathrm{I}$ & 480.200 & 480.200 & 54.5926 & 3.97 \\
\hline Dalam Kelompok & 76 & 668.500 & 8.796053 & & \\
\hline
\end{tabular}

Sebagai konsekuensi terjadinya interaksi, maka perlu dilakukan uji pengaruh sederhana (simple effect) untuk menguji perbedaan hasil belajar biologi antara kelompok siswa yang memiliki konsep diri akademik tinggi yang diberi teknik penilaian minute paper dan teknik penilaian muddiest point, dan perbedaan hasil belajar biologi antara kelompok siswa yang memiliki konsep diri akademik rendah yang diberi teknik penilaian minute paper dan teknik penilaian muddiest point. Hasil uji t-Dunnet dapat dirangkum dalam Tabel 2.

Tabel 2. Rangkuman Hasil Uji t-Dunnet

\begin{tabular}{cccc}
\hline $\begin{array}{c}\text { Perbandingan } \\
\text { Kelompok }\end{array}$ & \multicolumn{2}{c}{ Uji t-Dunnet } & Simpulan \\
\cline { 2 - 3 } & $\boldsymbol{t}_{\text {hitung }}$ & $\begin{array}{c}\boldsymbol{t}_{\text {tabel }} \\
(0,05)\end{array}$ & \\
\hline$A_{1} B_{1}-A_{2} B_{1}$ & $I 7,182$ & $I, 734$ & Tolak $H_{0}$ \\
\hline$A_{1} B_{2}-A_{2} B_{2}$ & 8,804 & $I, 734$ & Tolak $H_{0}$ \\
\hline
\end{tabular}


Berdasarkan hasil analisis varian (ANAVA) dua jalan ditemukan bahwa terdapat perbedaan hasil belajar biologi kelompok siswa yang diberi teknik penilaian minute paper dengan hasil belajar biologi kelompok siswa yang diberi teknik penilaian muddiest point. Selanjutnya untuk meyakinkan adanya perbedaan tersebut, maka dilanjutkan dengan uji t-Dunnet. Hal ini mempunyai arti bahwa rata-rata hasil belajar biologi kelompok siswa yang diberi teknik penilaian minute paper lebih tinggi dari rata-rata hasil belajar biologi kelompok siswa yang diberi teknik penilaian muddiest point.

Teknik penilaian minute paper yang diterapkan dikelas sedapat mungkin memiliki dua tujuan: I) menyelidiki seberapa baik siswa memahami konsep penting yang disajikan selama periode kelas. 2) Menyediakan wawasan terhadap peningkatan instruksi di kelas berhasil oleh modifikasi dalam presentasi. Minute paper bekerja dengan baik pada akhir atau mulai dari sesi kelas. Sebagai nilai tambah minute paper membantu siswa untuk mensintesis konsep-konsep kunci dan menerapkan pengetahuan melalui tugas singkat menulis di kelas. Siswa yang kurang memahami konsep-konsep kunci dapat menuliskannya dan pada saat menganalisis guru akan mengelompokkan konsep-konsep apa yang harus diperbaiki baik dalam bentuk penjelasan kembali, siswa diminta untuk membaca kembali, atau sekedar diskusi di kelas untuk menajamkan konsep-konsep kunci. Dengan adanya perbaikan dalam hal penguasaan konsep-konsep kunci yang dituliskan siswa dalam minute paper, siswa yang sebetulnya sudah memahami juga akan diingatkan kembali mengenai konsep tersebut dan makin tajam dalam penguasaan konsep tersebut.

Untuk merespon muddiest point ini siswa harus dengan cepat mengidentifikasi apa yang mereka tidak mengerti atau masih belum jelas. Sementara waktu yang digunakan untuk penilaian ini sangat singkat.

Kemungkinan siswa kesulitan dalam menuliskan hal-hal yang belum dipahami atau hal yang paling tidak dimengerti oleh siswa. Ketika siswa tidak menuliskan hal yang tidak dipahami yang sesungguhnya akan mempengaruhi informasi yang dikumpulkan guru mengenai hal-hal yang harus diperbaiki pada proses pembelajaran. Untuk pertama kali merupakan hal sulit bagi siswa diminta untuk fokus hanya pada apa yang mereka tidak mengerti. Sehingga yang seharusnya dapat diperbaiki untuk penguasaan konsep-konsep kunci menjadi tidak diperbaiki karena siswa tidak memberikan informasi yang dibutuhkan mereka. Konsep-konsep kunci yang harusnya diperbaiki penyampaiannya menjadi terlewatkan sehingga mempengaruhi penguasaan konsep-konsep tersebut.

Dari hasil uji t-Dunnet ini menunjukkan bahwa khusus kelompok siswa yang memiliki konsep diri tinggi, terdapat perbedaan hasil belajar biologi kelompok siswa yang diberi teknik penilaian minute paper dengan hasil belajar biologi kelompok siswa yang diberi teknik penilaian muddiest point.

Perbedaan ini ditunjukkan dengan nilai ratarata hasil belajar biologi kelompok siswa yang diberi teknik penilaian minute paper lebih besar dari nilai rata-rata hasil belajar kelompok siswa yang diberi teknik penilaian muddiest point. Ini mempunyai arti bahwa khusus kelompok siswa yang memiliki konsep diri akademik tinggi, terdapat perbedaan yang berarti antara hasil belajar biologi kelompok siswa yang diberi teknik penilaian minute paper dengan hasil belajar biologi kelompok siswa yang diberi teknik penilaian muddiest point. Hasil uji selanjutnya menunjukkan hasil yang mempunyai arti bahwa khusus kelompok yang memiliki konsep diri akademik tinggi, rata-rata hasil belajar biologi kelompok siswa yang diberi teknik penilaian minute paper lebih tinggi dari rata-rata hasil belajar biologi kelompok siswa yang diberi teknik penilaian muddiest point.

Dari penjelasan di atas dapat disimpulkan bahwa khusus kelompok siswa yang memiliki konsep diri akademik tinggi, hasil belajar biologi kelompok siswa yang diberi teknik penilaian minute paper lebih tinggi dari rata-rata hasil belajar biologi kelompok siswa yang diberi teknik penilaian muddiest point.

Selain karena perbedaan karakteristik minute paper dan muddiest point yang dampaknya berbeda terhadap siswa. Meskipun bila dilihat sekilas perbedaan teknik ini hanya dari apa yang ditulis siswa setelah pembelajaran usai, minute paper menuliskan hal-hal paling dimengerti. Sedangkan muddiest point hal-hal yang tidak dimengerti. Tetapi muddiest point membuat siswa merasa 
bingung ketika harus berfokus pada hal yang tidak dimengerti. mengakibatkan tidak utuhnya informasi yang sampai ke guru, sehingga guru menyampaikan sesuai analisis dari kartu muddiest point yang terkumpul.

Dari perbedaan di atas kemudian seolah-olah dikontraskan, siswa dikelompokkan dalam siswa yang memiliki konsep diri akademik tinggi. Konsep diri akademik secara global adalah persepsi siswa tentang kemampuan umumnya di sekolah. Namun, banyak peneliti berpendapat bahwa konsep diri akademik adalah multidimensi dan bervariasi di seluruh mata pelajaran sekolah. $\mathrm{Hal}$ ini yang mendasari bahwa dalam pelajaran biologi pun konsep diri akademik pada mata pelajaran biologi ini bervariasi pula.

Secara teori, konsep diri akademik seorang yang tinggi harus mengarah pada keuntungan dalam prestasi akademik. Konsep diri akademik, salah satu fitur afektif merupakan faktor penting yang mempengaruhi proses belajar dan demikian pula dengan prestasi peserta didik.

Konsep diri merupakan faktor yang sangat menentukan dalam berkomunikasi karena setiap orang bertingkah laku secepat mungkin sesuai dengan konsep dirinya bila siswa menganggap dirinya seorang yang rajin ia akan berusaha belajar dengan sungguh-sungguh sehingga memperoleh nilai akademis yang baik. Dari satu perspektif, siswa yang memiliki konsep diri yang lebih tinggi lebih mungkin untuk terlibat dalam tugas-tugas akademik, mengatur pembelajaran mereka, dan terlibat dalam strategi pembelajaran yang efektif untuk meningkatkan prestasi akademis.

Seseorang yang memiliki konsep diri akademik tinggi salah satunya mampu memperbaiki dirinya karena sanggup mengungkapkan aspek-aspek kepribadian yang tidak disenanginya dan berusaha untuk mengubahnya. Hal ini sangat berhubungan dengan penilaian minute paper dan muddiest point, siswa yang memiliki konsep diri akademik tinggi ada usaha untuk memperbaiki diri, menilai diri konsep-konsep apa saja yang sudah dipahami atau belum. Namun kendalanya di muddiest point, siswa merasa bingung mengidentifikasi hal-hal yang tidak dipahami dalam waktu singkat.

Di sisi lain, pada kelompok siswa yang memiliki konsep diri akademik rendah secara statistik menunjukkan bahwa terdapat perbedaan antara hasil belajar biologi kelompok siswa yang diberi teknik penilaian minute paper dengan hasil belajar biologi kelompok siswa yang diberi teknik penilaian muddiest point. Dari hasil analisis menunjukkan bahwa khusus kelompok siswa yang memiliki konsep diri akademik rendah terdapat perbedaan hasil belajar biologi kelompok siswa yang diberi teknik penilaian minute paper dengan hasil belajar biologi kelompok siswa yang diberi teknik penilaian muddiest point. Hal ini mempunyai arti bahwa khusus kelompok yang memiliki konsep diri akademik rendah, terdapat perbedaan antara hasil belajar biologi kelompok siswa yang diberi teknik penilaian minute paper dengan hasil belajar biologi kelompok siswa yang diberi teknik penilaian muddiest point. hasil uji t-Dunnet mempunyai arti bahwa khusus kelompok siswa yang memiliki konsep diri akademik rendah, ratarata hasil belajar biologi kelompok siswa yang diberi teknik penilaian minute paper lebih tinggi dari rata-rata hasil belajar biologi kelompok siswa yang diberi teknik penilaian muddiest point.

Karena konsep diri akademik faktor yang sangat menentukan dalam berkomunikasi, siswa yang menganggap dirinya rajin ia akan berusaha belajar dengan sungguh-sungguh sehingga memperoleh nilai akademis yang baik. Namun sebaliknya, siswa yang memiliki konsep diri rendah akan cenderung memiliki keberhasilan belajar yang rendah. Siswa yang memiliki konsep diri yang rendah atau negatif akan memandang dunia sekitarnya secara negatif. Siswa yang memiliki konsep diri rendah cenderung menghindar dan untuk berkomunikasi dengan teman belajar, bersikap pesimis terhadap kompetisi dalam belajar, enggan bersaing dengan orang lain dalam membuat prestasi, dan merasa tidak disenangi orang lain, sehingga hal ini sangat berpengaruh terhadap perkembangan belajar sehingga hasil belajarnya cenderung tidak sesuai dengan yang diharapkan.

Konsep diri yang rendah bagi siswa menimbulkan kurangnya kepercayaan pada kemampuan sendiri. Siswa tersebut tidak akan menyenangi dirinya dan merasa tidak mampu dalam mengenali diri dalam pergaulan cenderung merasa tidak menarik bagi orang lain, cenderung malas, dan mengakibatkan cenderung gagal secara akademis.

Kondisi kelompok siswa yang memiliki konsep diri yang rendah seperti penjelasan di atas 
memungkinkan siswa ketika diminta untuk menilai dirinya menuangkan dalam tulisan hal-hal yang dimengerti atau tidak, menjadi kendala karena mereka kurang mampu berkomunikasi meskipun dalam bentuk tulisan. Sehingga apa yang seharusnya dapat mereka perbaiki dalam hal-hal penguasaan konsep-konsep kunci menjadi luput. Namun untuk kelompok siswa yang diberi teknik penilaian minute paper terbantu oleh siswa yang memiliki konsep diri tinggi yang mampu menuliskan keterbatasan dirinya dalam penguasaan konsep-konsep kunci. Hasil minute paper di setiap pertemuan menunjukkan hasil yang hampir sama kecuali untuk yang konsep diri akademiknya rendah. Dari informasi siswa yang memiliki konsep diri tinggilah guru mendapatkan informasi utuh sehingga guru akan memperbaiki konsep-konsep yang belum dikuasai siswa dan ternyata siswa yang memiliki konsep diri rendah pun yang belum menguasai konsep tersebut akan terbantu.

Berbeda halnya dengan kelompok yang diberi penilaian muddiest point untuk kelompok yang memiliki konsep diri tinggi saja masih mengalami kesulitan untuk mengidentifikasi hal-hal yang tidak dipahami dalam waktu singkat apalagi kelompok yang memiliki konsep diri rendah. Kelompok konsep diri rendah ini lemah dalam mengidentifikasi hal-hal mengenai dirinya apa lagi dalam perbaikan pemahaman, mereka cenderung tidak merasa penting untuk memperbaiki keadaannya. Dari keadaan tersebut guru tidak memperoleh informasi yang utuh tentang apa saja yang perlu diperbaiki dalam penguasaan konsepkonsep kunci pada kelompok muddiest point ini.

\section{Kesimpulan}

Berdasarkan hasil pengujian hipotesis, maka dikemukakan beberapa kesimpulan, sebagai berikut: (I) hasil belajar biologi kelompok siswa yang diberi teknik penilaian minute paper lebih tinggi dari hasil belajar biologi kelompok siswa yang diberi teknik penilaian muddiest point; (2) terdapat pengaruh interaksi antara classroom assessment techniques (CATs) dan konsep diri akademik terhadap hasil belajar biologi siswa; (3) khusus kelompok siswa yang memiliki konsep diri akademik tinggi, hasil belajar biologi kelompok siswa yang diberi teknik penilaian minute paper lebih tinggi dari hasil belajar biologi kelompok siswa yang diberi teknik penilaian muddiest point; (4) khusus kelompok siswa yang memiliki konsep diri akademik rendah, hasil belajar biologi kelompok siswa yang diberi teknik penilaian minute paper lebih tinggi dari hasil belajar biologi kelompok siswa yang diberi teknik penilaian muddiest point.

\section{Daftar Pustaka}

Angelo, Thomas A. dan K. Patricia Cross. (1993). Classroom Assessment Techniques a Handbook for College Teachers. San Fransisco: Jossey-Bass Publishers.

Hurlock, Elizabet B. (1996). Psikologi Perkembangan: Suatu Kehidupan Sepanjang Kehidupan. Edisi Kelima. Jakarta: Penerbit Erlangga.

Kadir. (20I5). Statistika Terapan. Jakarta: Raja Grafindo Persada.

Marzano, Robert J. (2006). Classroom Assessment and Grading that Work. Virginia: SCD.

Popham, W James. (2008). Penilaian Berbasis Kelas: What Teacher Need to Know. Boston: Pearson.

Yusuf, A. Muri. (20I5). Asesmen dan Evaluasi Pendidikan. Jakarta: Kencana. 